\title{
Effects of Soil Rehydration on the Virulence of Entomopathogenic Nematodes
}

\author{
JENNIFER A. GRANT ${ }^{1}$ AND MICHAEL G. VILLANI ${ }^{2}$ \\ Department of Entomology, Cornell University, NYSAES, Geneva, NY 14456-0462
}

Environ. Entomol. 32(5): 983-991 (2003)

\begin{abstract}
The work presented examines the effects of soil moisture on the virulence of selected entomopathogenic nematode isolates in the laboratory and has broad implications for managing soil-dwelling insects in all production systems. Two species of entomopathogenic nematodes, Heterorhabditis bacteriophora (Oswego and Tuscarora strains) and Steinernema glaseri (NCl strain), were applied to sandy loam soils ranging from below the permanent wilting point of plants to near saturation. Fluctuations in soil moisture were created by simulating a rainfall or irrigation event (i.e., rehydration), or by allowing soil to dry. Nematode virulence was evaluated by measuring insect mortality in Galleria mellonella larvae bioassays. Soils prepared at four moisture contents were inoculated with nematodes and subsequently bioassayed at their original moisture contents and after rehydration, over an 18-mo period. Insect mortality increased with soil moisture content for both $H$. bacteriophora isolates but was highest in relatively low moisture soils $(\approx-15$ bar $)$ for $S$. glaseri. Insect mortality was generally low in low-moisture soils before rehydration but rebounded to high levels posthydration. Both isolates of $H$. bacteriophora nematodes were reactivated to cause high insect mortality $(\geq 98 \%)$ as long as 18 mo after infective juveniles were inoculated into very low moisture soils $(\approx-30 \mathrm{bar})$. The posthydration insect mortality levels in the S. glaseri treatments were significantly lower than in the $H$. bacteriophora treatments. For all nematode treatments, the cumulative insect mortality of prehydration and posthydration bioassays was higher in lower moisture soils compared with higher moisture soils. In an additional experiment, moisture thresholds for activation of nematodes in dry soil were determined.
\end{abstract}

KEY WORDS Entomopathogenic nematodes, soil moisture, Heterorhabditis bacteriophora, Steinernema glaseri, biological control

ENTOMOPATHOGENIC NEMATODES are well adapted to infect soil-dwelling insect pests, and have been shown to be important biological control agents in a variety of ornamental and crop production systems (Kaya and Gaugler 1993, Georgis and Manweiler 1994, Gaugler et al. 1997). Nematode performance may be influenced by many abiotic environmental factors, including soil moisture (Koppenhöfer et al. 1995, Fujiie et al. 1996), temperature (Kung et al. 1991, Griffin 1993), light (Gaugler et al. 1992, Fujiie and Yokoyama 1998), and soil texture and bulk density (Ames 1990, PortilloAguilar et al. 1999, Smith 1999). Entomopathogenic nematodes need a film of free water for movement and may become dormant at very low soil moistures (Womersley 1990, Smits 1996, Smith 1999). Therefore, moisture conditions have been recognized as one of the most important factors in the soil environment affecting survival, virulence, and persistence of nematodes (Klein 1990, Curran 1993).

\footnotetext{
${ }^{1}$ Current address: NYS IPM Progarm, Cornell University, NYSAES, Geneva, NY 14456 (e-mail: jag7@cornell.edu).

${ }^{2}$ Deceased.
}

Previous studies (Kung et al. 1991, Koppenhöfer et al. 1995, Grant and Villani 2003) have shown that low levels of nematode-induced insect mortality in lowmoisture soils could "rebound" to high levels by adding water. In these studies, rebounds were successfully initiated after 1-96 days of exposure to low moisture conditions. Most researchers have focused on steinernematid nematodes, and only a few (Kung et al. 1991, Koppenhöfer et al. 1995, Grant and Villani 2003) conducted their work in a soil environment. Solely our previous study (Grant and Villani 2003) tested a heterorhabditid nematode in soil.

The goal of our research was to determine the impact of long-term $(>96 \mathrm{~d}$ ) storage on the ability of entomopathogenic nematodes to rebound and kill insects when soils are rehydrated. This information may aid the selection of nematode species and/or isolates that are able to survive low moisture conditions for long periods of time in the field. We also sought to determine the specific soil moisture thresholds at which these nematodes would reactivate to commence infecting insects. Determination of these thresholds may suggest the manipulation of field con- 
ditions to activate nematodes. These studies may also impact product formulation methods, since dehydration is commonly used for formulation of nematodes as pest management products.

In this paper we report on two experiments that were conducted to study the response of two species of entomopathogenic nematodes, Heterorhabditis bacteriophora (Oswego and Tuscarora strains) and Steinernema glaseri (NC1 strain), to increasing or decreasing soil moisture. Although we used Galleria mellonella as our test organism, we are ultimately interested in the management of scarab grubs. Therefore, we chose nematode species and isolates for our experiments that had shown efficacy against grubs. The first experiment, a long-term rehydration study, was designed to study the virulence of nematodes in soils at various moistures that were rehydrated up to 18-mo after inoculation. Another experiment was designed to examine the soil moisture thresholds required to reactivate entomopathogenic nematodes.

\section{Materials and Methods}

Insect Host. Late-instar larvae of the greater wax moth, Galleria mellonella (L.) (Lepidoptera: Galleridae) were used both as hosts for rearing nematodes and as indicators of nematode infection in soil bioassays. Wax moth larvae were heat-treated by the supplier (Sunfish Bait Farm, Webster, WI) to prevent web spinning and packed in sawdust for shipping. Once received at our laboratory, larvae were held at $10^{\circ} \mathrm{C}$ and used for experiments within $2 \mathrm{wk}$ of receipt. Wax moth larvae were placed in nematode-inoculated soil for three d, which is sufficient for nematodes and bacteria to enter and kill insects but not long enough for new nematode progeny to reinoculate the soil (Simoes and Rosa 1996, Boemare et al. 1997).

Nematodes. Two nematode species were tested: Heterorhabditis bacteriophora Poinar (Oswego and Tuscarora strains) and Steinernema glaseri Steiner (NCl strain). Both isolates of $H$. bacteriophora were originally collected in upstate New York, and the $S$. glaseri isolate was collected in NC. Nematodes were reared in wax moth larvae for multiple generations in our laboratory following the procedures of Kaya and Stock (1997). Third-instar infective juvenile nematodes (IJ) were harvested from water surrounding White traps (White 1927) within $10 \mathrm{~d}$ of emerging from their hosts, and applied to experimental units at rates roughly equivalent to the field recommendation of one billion IJ per acre of surface area. Exact rates are specified for each experiment.

Soil. Sandy loam soil used in our studies was $60 \%$ sand, $30 \%$ silt, $10 \%$ clay, $2.8 \%$ organic matter, and $\mathrm{pH}$ 5.7. Before use, the soil was frozen for $48 \mathrm{~h}\left(-8 \pm 1^{\circ} \mathrm{C}\right)$ to reduce the population of endemic soil microarthropods and microbes, and screened twice through 2.36-mm mesh to remove debris and improve uniformity. Soil moisture contents were obtained by weighing and oven drying soil samples ( $15 \pm 5 \mathrm{~g}$ ) (Hillel 1998) and calculated on a wet weight (wt:wt) basis. Soil moisture adjustments for both experiments were calculated to increase soil moistures to the target range for each treatment, and the appropriate amount of distilled water was added and mixed into the soil. The water potentials of these soils were determined by a filter paper equilibration method (Kaya and Stock 1997), and estimated as $-30,-15,-2 \mathrm{bar}$, and $-0.1 \mathrm{bar}$ for $6 \%, 9 \%, 12 \%$, and $15 \%$ soil moisture (wt:wt), respectively.

\section{Experimental Design}

Long-term Rehydration Study. In the first experiment, we determined the virulence of nematodes in soils that were rehydrated up to 18 mo after inoculation. Sandy loam soil was prepared at a range of soil moistures and inoculated with one of three nematode isolates. Periodically during the 18-mo experiment, soil was bioassayed to evaluate insect mortality before and after the addition of water to soils.

Six batches of soil were prepared at each of four target soil moistures $(6 \%, 9 \%, 12 \%, 15 \%$ wt:wt). Selfsealing plastic bags ( 15 by $15 \mathrm{~cm}$ ) were filled with soil $(450 \pm 1 \mathrm{~g})$ and inoculated with one of four treatments (H. bacteriophora (Oswego), H. bacteriophora [Tuscarora]), S. glaseri, or a no-nematode check). Nematode IJ were applied in $1 \mathrm{ml}$ of distilled water onto the soil surface in each bag at rates of 1,990 $\pm 102(H$. bacteriophora [Oswego]), 1,825 \pm 90 (H. bacteriophora [Tuscarora] ), and 1,950 180 (S. glaseri). Nematode-inoculated soil was stored in self-sealing plastic bags to minimize moisture loss but later transferred to plastic cups for bioassays. The inoculation rates resulted in $\approx 1$ billion IJ per acre of surface area in the bioassay containers. Bioassay groups contained six replicate bags (one from each soil moisture batch) for each of the 16 nematode-soil moisture combinations (four nematode treatments, four moistures). Therefore, 96 bags were destructively bioassayed at each of 13 sampling periods, for a total of 1,248 bags. The bags were randomly positioned and held in an environmental chamber at $25 \pm 2^{\circ} \mathrm{C}$ and $60 \% \pm 5 \% \mathrm{RH}$ until their removal for bioassaying.

Prehydration bioassays were conducted 13 times over an 18 mo period $(5,9,13,17,21,25,29,32,37,45$, 53,61 , and $74 \mathrm{wk}$ after set-up). For each bioassay, six bags from each soil moisture and/or nematode treatment combination (one from each soil batch) were removed from the environmental chamber. Soil was transferred from the bags into individual plastic cups (480-ml, Fabri-Kal, Kalamazoo, MI), and a sample $(15 \pm 5 \mathrm{~g})$ was taken from each cup for soil moisture determination. Ten wax moth larvae were placed on the soil surface in each cup, and cups were capped and inverted to ensure soil-to-insect contact. After $72 \mathrm{~h}$, wax moth larvae were removed and examined for mortality.

The soil in each cup was rehydrated to $15.5 \%$ (as described in the soil section), after larval removal, and allowed to equilibrate for four-five days. A posthydration bioassay was initiated after moisture equilibration, with the same procedure as the prehydration bioassay. 
A series of exhaustive bioassays was designed to determine long-term nematode virulence and assess the effect of soil moisture on the cumulative insect mortality (CIM) of the various treatments. Four days after completion of the bioassays in rehydrated soils, exhaustive bioassays were initiated. Procedures were the same as in previous assays, except that $20 \mathrm{G}$. mellonella larvae were added to each container and removed after one day. The soil was bioassayed on three consecutive days with 20 larvae/container/d. Larvae were held for two additional days in petri plates before mortality counts were taken. These assays were conducted after eight of the posthydration bioassays (weeks 6, 10, 14, 18, 22, 26, 30, and 38). Insect mortality from these bioassays was combined with prehydration and posthydration mortality counts to produce a cumulative mortality count for each treatment.

Nematode Reactivation Study. Reactivation thresholds were ascertained by exposing inactive nematodes inhabiting low moisture soil to a range of higher moisture conditions to determine the soil moisture at which each nematode isolate caused insect mortality. Two hundred and forty plastic cups (30-ml, Comet Products, Chelmsford, MA) were filled with soil $(28.8 \pm 0.26 \mathrm{~g})$ at $9.0 \%$ moisture (wt:wt). One of four treatments (H. bacteriophora [Oswego], H. bacteriophora [Tuscarora], S. glaseri, or a no-nematode control) were delivered in $1 \mathrm{ml}$ of distilled water onto the soil surface in each cup at rates of 2,060 $\pm 189 \mathrm{IJ}(H$. bacteriophora [Oswego]), 1,890 $\pm 127 \mathrm{IJ}$ (H. bacteriophora [Tuscarora]), and 2,140 $\pm 95 \mathrm{IJ}$ (S. glaseri). Nematodes were inoculated at these high rates to compensate for the soil dilution that was later imposed during the soil moisture adjustment. Additional water control cups were set up for assessment and monitoring of soil moisture levels during the experiment. Cups were randomly distributed into plastic trays. Each tray of cups was enclosed in a plastic bag to minimize moisture fluctuation and held at $25 \pm 2^{\circ} \mathrm{C}$ and $60 \pm 5 \%$ $\mathrm{RH}$.

Our goal was to start with this moderately dry soil $(9.0 \%)$, and reduce the soil moisture in each cup slowly and uniformly within the soil mass, until nematode activity was minimal (i.e., insect mortality $\leq$ $7 \%$ ). Nematodes survive desiccation better when dried slowly from a higher moisture condition rather than being placed directly in an extremely dry environment (Simons and Poinar 1973, Womersley et al. 1998). Therefore, we chose to dry soil slowly from $9 \%$, a technique that was successful in our previous experiments. To promote slow and uniform drying, soil was poured from each cup and returned to the cup once a week for the $7 \mathrm{wk}$ before moisture adjustment. Bioassays were conducted 2, 9, 16, 30, and $48 \mathrm{~d}$ after the experiment was set up. Each cup received one wax moth larva on the soil surface that was removed after a 72-h exposure and examined for mortality. In the fifth bioassay (at $48 \mathrm{~d}$ ), insect mortality in each of the four treatments (three nematodes and a control) averaged $\leq 7 \%$, and the soil moisture was $5.2 \pm 0.05 \%$.

At $56 \mathrm{~d}$, soil moistures were adjusted by incorporating the nematode-inoculated soil in each 30-ml cup into a larger quantity of soil $(275 \pm 1 \mathrm{~g})$ to create a range of 10 target soil moistures (5\%-14\% wt:wt). Soil was transferred into larger cups (240-ml capacity), allowed to equilibrate, and was subsequently bioassayed $9 \mathrm{wk}$ after the experiment had been set up (i.e., six d after the moisture adjustment). For this post moisture-adjustment bioassay, 10 wax moth larvae were placed on the soil surface, removed after a 72-h exposure, and examined for mortality. Actual soil moistures at bioassay were 5.1, 6.1 , 7.6, 8.0, 9.2, 9.6, 10.9, 11.6, 12.5, and 13.3.

Soil moisture was determined in three monitor cups at the end of each bioassay before the moisture adjustment, and on the days moistures were adjusted. At the post moisture-adjustment bioassay (i.e., $9 \mathrm{wk}$ ), soil samples $(15 \pm 5 \mathrm{~g})$ were removed from one-third of the cups (two/treatment) for moisture content assessment.

\section{Statistics}

Data from the long-term rehydration study were analyzed using statistical software (SAS Institute 1996). Prehydration and CIM, and soil moisture were analyzed using general linear model, followed by post hoc tests using Tukey corrections for multiple comparisons. The rebound from prehydration to posthydration mortality was compared using a Student paired sample $t$-test. Significance is reported when $P \leq$ 0.05 .

For the reactivation experiment, data were fit to a logistic model comprised of two categorical factors to identify the nematode strain, and soil moisture, which was a continuous independent variable, and the interaction between nematode strain and soil moisture. The model was fit using Stata (StataCorp 2001), with a robust variance estimator. The robust variance estimator allowed for correlation in response by the wax moth larvae within each cup used in the assay. Recall that 10 wax moth larvae were placed into each cup. $H$. bacteriophora (Tuscarora) was used as the reference nematode isolate for the model. Following estimation of model parameters, predicted wax moth mortality, 95\% CL for these predictions, and estimated wax moth mortality were plotted.

\section{Results}

\section{Long-term Rehydration Study}

Reported insect mortality levels in the long-term rehydration study were corrected for control mortality with the Abbott formula (Abbott 1925).

Prehydration Insect Mortality. Insect mortality was $\leq 15 \%$ in the control treatments and in the lowest moisture soils (6\% wt:wt) for all three nematode isolates tested in the prehydration bioassays throughout the 18 mo (Fig. 1). The model for effects of nematode isolate, soil moisture, and time was complex, with all two and three-way interactions being significant. When analyzing by soil moisture, insect mortality differed significantly by nematode isolate at $9 \%$ and $15 \%$ 
A) $6 \%$ Soil Moisture

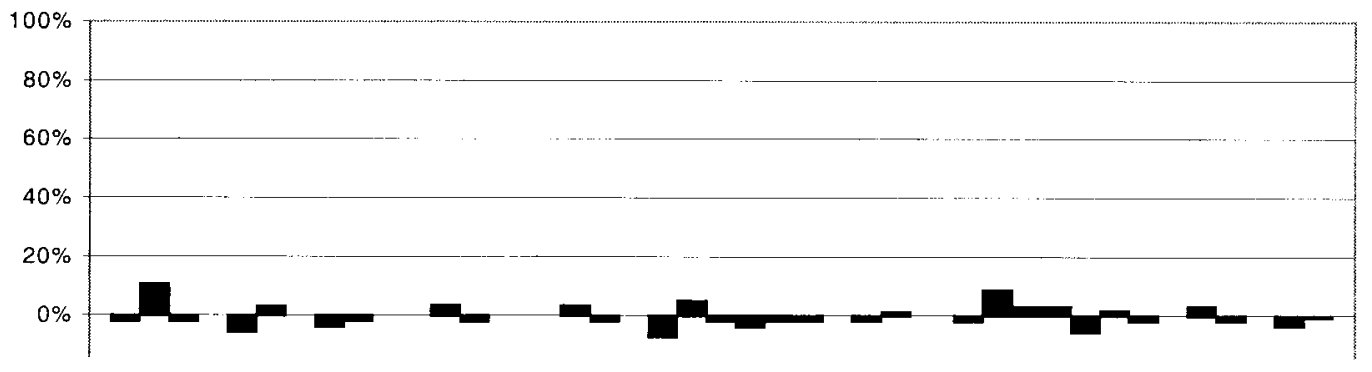

B) $9 \%$ Soil Moisture

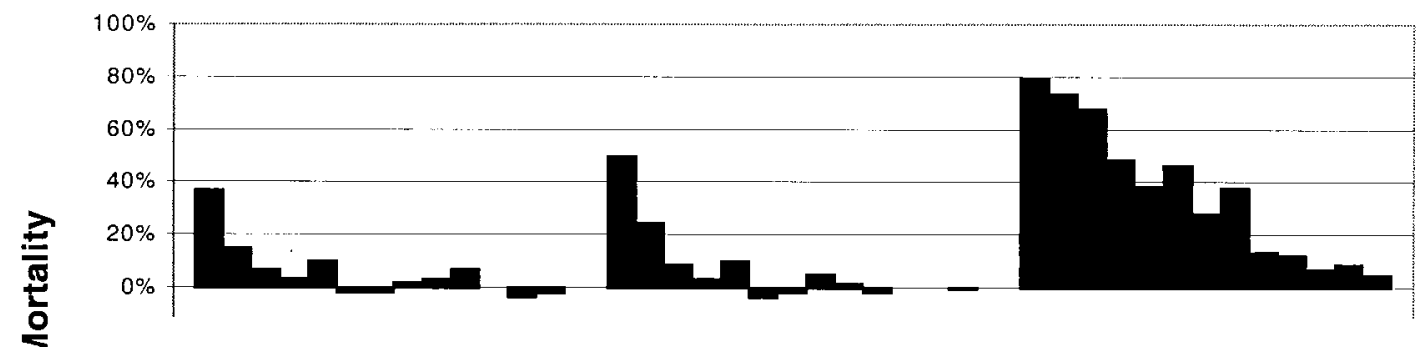

C) $12 \%$ Soil Moisture

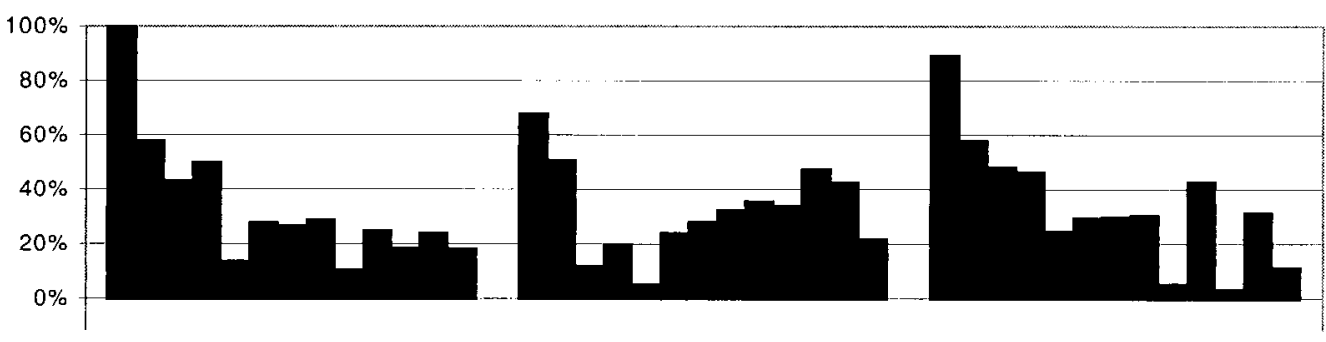

D) $\mathbf{1 5} \%$ Soil Moisture

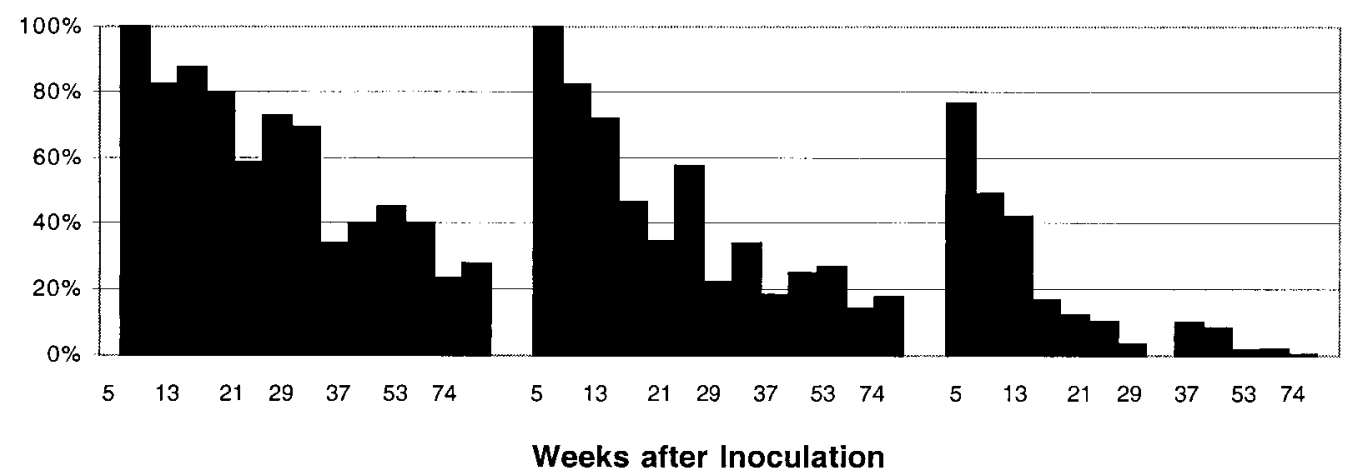

H. bacteriophora (Tuscarora)

\section{H. bacteriophora \\ (Oswego)}

S. glaseri

Fig. 1. Wax moth mortality in soil inoculated with H. bacteriophora (Oswego), H. bacteriophora (Tuscarora), and S. glaseri (NC1) nematodes, prehydration, in the long-term rehydration experiment at various soil moistures.

soil moisture $(F=78.49 ; \mathrm{df}=9,108 ; P=0.0001)$. Insect mortality was significantly higher in the $S$. glaseri treatments than other treatments at $9 \%$ soil moisture. At
$15 \%$ soil moisture, mortality levels in $H$. bacteriophora (Tuscarora) were greater than $H$. bacteriophora (Oswego), which was greater than S. glaseri. In $9 \%$ mois- 
Table 1. Wax moth mortality prehydration and posthydration in three nematode treatments (i.e., H. bacteriophora [Oswego], H. bacteriophora [Tuscarora], and S. glaseri [NC1]) and four prehydration soil moistures $(6 \%, 9 \%, 12 \%$, and $15 \%)$ in the long-term rehydration study

\begin{tabular}{|c|c|c|c|c|c|c|c|c|c|c|c|c|c|}
\hline \multirow{3}{*}{ Wk } & & \multicolumn{4}{|c|}{ H. bacteriophora (Tuscarora) } & \multicolumn{4}{|c|}{ H. bacteriophora (Oswego) } & \multicolumn{4}{|c|}{ S. glaseri } \\
\hline & & \multicolumn{4}{|c|}{ Soil Moisture } & \multicolumn{4}{|c|}{ Soil Moisture } & \multicolumn{4}{|c|}{ Soil Moisture } \\
\hline & & $6 \%$ & $9 \%$ & $12 \%$ & $15 \%$ & $6 \%$ & $9 \%$ & $12 \%$ & $15 \%$ & $6 \%$ & $9 \%$ & $12 \%$ & $15 \%$ \\
\hline 5 & PRE & $-2 \%$ & $37 \%$ & $99 \%$ & $100 \%$ & $0 \%$ & $50 \%$ & $68 \%$ & $100 \%$ & $-2 \%$ & $79 \%$ & $89 \%$ & $77 \%$ \\
\hline \multirow[t]{2}{*}{6} & POST & $100 \%$ & $98 \%$ & $65 \%$ & $76 \%$ & $100 \%$ & $98 \%$ & $93 \%$ & $58 \%$ & $84 \%$ & $91 \%$ & $24 \%$ & $16 \%$ \\
\hline & Change & $102 \% *$ & $61 \% *$ & $-33 \%$ * & $-24 \% *$ & $100 \% *$ & $48 \%$ * & $25 \% \mathrm{NS}$ & $-42 \% *$ & $86 \% *$ & $12 \% \mathrm{NS}$ & $-66 \% *$ & $-61 \% *$ \\
\hline 9 & PRE & $11 \%$ & $15 \%$ & $58 \%$ & $82 \%$ & $4 \%$ & $24 \%$ & $51 \%$ & $81 \%$ & $9 \%$ & $73 \%$ & $58 \%$ & $59 \%$ \\
\hline \multirow[t]{2}{*}{10} & POST & $100 \%$ & $91 \%$ & $65 \%$ & $69 \%$ & $100 \%$ & $96 \%$ & $79 \%$ & $81 \%$ & $89 \%$ & $89 \%$ & $32 \%$ & $5 \%$ \\
\hline & Change & $89 \% *$ & $76 \% *$ & $6 \%$ NS & $-13 \% \mathrm{NS}$ & $96 \% *$ & $72 \% *$ & $28 \% *$ & $0 \% \mathrm{NS}$ & $80 \% *$ & $16 \% \mathrm{NS}$ & $-26 \% \mathrm{NS}$ & $-44 \% \mathrm{NS}$ \\
\hline 13 & PRE & $-2 \%$ & $7 \%$ & $41 \%$ & $88 \%$ & $-2 \%$ & $8 \%$ & $12 \%$ & $72 \%$ & $3 \%$ & $68 \%$ & $48 \%$ & $42 \%$ \\
\hline \multirow[t]{2}{*}{14} & POST & $100 \%$ & $92 \%$ & $41 \%$ & $77 \%$ & $100 \%$ & $100 \%$ & $97 \%$ & $78 \%$ & $82 \%$ & $77 \%$ & $14 \%$ & $15 \%$ \\
\hline & Change & $102 \% *$ & $85 \% *$ & $-1 \% \mathrm{NS}$ & $-11 \% \mathrm{NS}$ & $101 \% *$ & $92 \% *$ & $85 \% *$ & $6 \% \mathrm{NS}$ & $78 \% *$ & $9 \% \mathrm{NS}$ & $-35 \% *$ & $-27 \% *$ \\
\hline 17 & PRE & $0 \%$ & $3 \%$ & $50 \%$ & $80 \%$ & $0 \%$ & $3 \%$ & $20 \%$ & $46 \%$ & $3 \%$ & $48 \%$ & $47 \%$ & $17 \%$ \\
\hline \multirow[t]{2}{*}{18} & POST & $98 \%$ & $86 \%$ & $49 \%$ & $69 \%$ & $100 \%$ & $98 \%$ & $76 \%$ & $48 \%$ & $65 \%$ & $72 \%$ & $31 \%$ & $10 \%$ \\
\hline & Change & $98 \% *$ & $83 \% *$ & $-1 \% \mathrm{NS}$ & $-11 \% \mathrm{NS}$ & $100 \% *$ & $95 \% *$ & $56 \% *$ & $2 \% \mathrm{NS}$ & $62 \% *$ & $24 \% *$ & $-16 \%$ NS & $-6 \%$ NS \\
\hline 21 & PRE & $-5 \%$ & $10 \%$ & $14 \%$ & $59 \%$ & $-7 \%$ & $10 \%$ & $5 \%$ & $34 \%$ & $-5 \%$ & $38 \%$ & $25 \%$ & $12 \%$ \\
\hline \multirow[t]{2}{*}{22} & POST & $100 \%$ & $83 \%$ & $59 \%$ & $50 \%$ & $100 \%$ & $98 \%$ & $88 \%$ & $54 \%$ & $32 \%$ & $62 \%$ & $22 \%$ & $6 \%$ \\
\hline & Change & $105 \% *$ & $73 \% *$ & $46 \% *$ & $-9 \%$ NS & $107 \% *$ & $88 \% *$ & $83 \% *$ & $19 \% \mathrm{NS}$ & $37 \% *$ & $23 \% *$ & $-2 \% \mathrm{NS}$ & $-6 \%$ NS \\
\hline 25 & PRE & $3 \%$ & $-2 \%$ & $28 \%$ & $73 \%$ & $5 \%$ & $-4 \%$ & $24 \%$ & $58 \%$ & $2 \%$ & $46 \%$ & $29 \%$ & $9 \%$ \\
\hline \multirow[t]{2}{*}{26} & POST & $100 \%$ & $89 \%$ & $47 \%$ & $48 \%$ & $100 \%$ & $89 \%$ & $77 \%$ & $53 \%$ & $57 \%$ & $70 \%$ & $19 \%$ & $9 \%$ \\
\hline & Change & $97 \% *$ & $91 \% *$ & $20 \% *$ & $-25 \% \mathrm{NS}$ & $95 \% *$ & $93 \% *$ & $53 \% *$ & $-4 \% \mathrm{NS}$ & $55 \% *$ & $23 \% *$ & $-10 \% \mathrm{NS}$ & $-1 \%$ NS \\
\hline 29 & PRE & $0 \%$ & $-2 \%$ & $27 \%$ & $69 \%$ & $-2 \%$ & $-2 \%$ & $28 \%$ & $22 \%$ & $-2 \%$ & $28 \%$ & $30 \%$ & $3 \%$ \\
\hline \multirow[t]{2}{*}{30} & POST & $98 \%$ & $95 \%$ & $74 \%$ & $66 \%$ & $100 \%$ & $93 \%$ & $78 \%$ & $42 \%$ & $25 \%$ & $71 \%$ & $19 \%$ & $4 \%$ \\
\hline & Change & $98 \% *$ & $97 \% *$ & $47 \%$ NS & $-4 \% \mathrm{NS}$ & $102 \% *$ & $95 \%$ * & $49 \% *$ & $20 \% \mathrm{NS}$ & $26 \% *$ & $43 \% *$ & $-11 \% \mathrm{NS}$ & $0 \%$ NS \\
\hline 32 & PRE & $-4 \%$ & $2 \%$ & $29 \%$ & $34 \%$ & $-4 \%$ & $5 \%$ & $32 \%$ & $34 \%$ & $0 \%$ & $38 \%$ & $31 \%$ & $-1 \%$ \\
\hline \multirow[t]{2}{*}{33} & POST & $100 \%$ & $90 \%$ & $49 \%$ & $39 \%$ & $100 \%$ & $85 \%$ & $56 \%$ & $28 \%$ & $23 \%$ & $92 \%$ & $19 \%$ & $-2 \%$ \\
\hline & Change & $104 \% *$ & $88 \% *$ & $20 \% *$ & $5 \% \mathrm{NS}$ & $104 \% *$ & $80 \%$ * & $24 \% *$ & $-6 \% \mathrm{NS}$ & $23 \% *$ & $54 \% *$ & $-12 \% \mathrm{NS}$ & $0 \%$ NS \\
\hline 37 & PRE & $-2 \%$ & $3 \%$ & $11 \%$ & $39 \%$ & $-2 \%$ & $2 \%$ & $36 \%$ & $18 \%$ & $3 \%$ & $13 \%$ & $5 \%$ & $10 \%$ \\
\hline \multirow[t]{2}{*}{38} & POST & $98 \%$ & $91 \%$ & $59 \%$ & $42 \%$ & $100 \%$ & $90 \%$ & $76 \%$ & $29 \%$ & $19 \%$ & $55 \%$ & $12 \%$ & $14 \%$ \\
\hline & Change & $100 \% *$ & $88 \% *$ & $48 \% *$ & $3 \% \mathrm{NS}$ & $102 \% *$ & $88 \% *$ & $40 \% *$ & $10 \% \mathrm{NS}$ & $15 \%$ NS & $42 \% *$ & $7 \% \mathrm{NS}$ & $4 \% \mathrm{NS}$ \\
\hline 45 & PRE & $0 \%$ & $7 \%$ & $25 \%$ & $45 \%$ & $-2 \%$ & $-2 \%$ & $34 \%$ & $25 \%$ & $-2 \%$ & $12 \%$ & $43 \%$ & $8 \%$ \\
\hline \multirow[t]{2}{*}{46} & POST & $100 \%$ & $98 \%$ & $58 \%$ & $54 \%$ & $100 \%$ & $93 \%$ & $80 \%$ & $38 \%$ & $26 \%$ & $60 \%$ & $8 \%$ & $7 \%$ \\
\hline & Change & $100 \% *$ & $91 \% *$ & $33 \%$ NS & $9 \%$ NS & $102 \% *$ & $95 \% *$ & $46 \% *$ & $13 \% \mathrm{NS}$ & $28 \% *$ & $48 \%$ * & $-35 \%$ * & $-1 \%$ NS \\
\hline 53 & PRE & $0 \%$ & $0 \%$ & $19 \%$ & $40 \%$ & $0 \%$ & $0 \%$ & $47 \%$ & $27 \%$ & $0 \%$ & $7 \%$ & $3 \%$ & $1 \%$ \\
\hline \multirow[t]{2}{*}{54} & POST & $100 \%$ & $92 \%$ & $63 \%$ & $47 \%$ & $100 \%$ & $85 \%$ & $83 \%$ & $51 \%$ & $17 \%$ & $38 \%$ & $15 \%$ & $0 \%$ \\
\hline & Change & $100 \% *$ & $92 \% *$ & $45 \% *$ & $7 \% \mathrm{NS}$ & $100 \% *$ & $85 \% *$ & $36 \% *$ & $24 \% \mathrm{NS}$ & $17 \% *$ & $32 \% *$ & $12 \% *$ & $-1 \%$ NS \\
\hline 61 & PRE & $3 \%$ & $-3 \%$ & $24 \%$ & $23 \%$ & $-2 \%$ & $0 \%$ & $43 \%$ & $14 \%$ & $-3 \%$ & $9 \%$ & $31 \%$ & $2 \%$ \\
\hline \multirow[t]{2}{*}{62} & POST & $100 \%$ & $90 \%$ & $25 \%$ & $19 \%$ & $100 \%$ & $88 \%$ & $70 \%$ & $34 \%$ & $3 \%$ & $59 \%$ & $43 \%$ & $0 \%$ \\
\hline & Change & $97 \% *$ & $93 \% *$ & $1 \% \mathrm{NS}$ & $-5 \% \mathrm{NS}$ & $102 \% *$ & $88 \%$ * & $27 \% \mathrm{NS}$ & $20 \% \mathrm{NS}$ & $6 \%$ NS & $41 \% *$ & $12 \% \mathrm{NS}$ & $-2 \% \mathrm{NS}$ \\
\hline 74 & PRE & $-2 \%$ & $-2 \%$ & $18 \%$ & $28 \%$ & $1 \%$ & $0 \%$ & $22 \%$ & $18 \%$ & $0 \%$ & $4 \%$ & $11 \%$ & $0 \%$ \\
\hline \multirow[t]{2}{*}{75} & POST & $100 \%$ & $95 \%$ & $62 \%$ & $32 \%$ & $100 \%$ & $100 \%$ & $95 \%$ & $48 \%$ & $0 \%$ & $20 \%$ & $10 \%$ & $0 \%$ \\
\hline & Change & $102 \% *$ & $97 \% *$ & $44 \% *$ & $4 \% \mathrm{NS}$ & $99 \% *$ & $100 \% *$ & $73 \% *$ & $31 \% \mathrm{NS}$ & $0 \% \mathrm{NS}$ & $16 \% \mathrm{NS}$ & $-1 \% \mathrm{NS}$ & $0 \% \mathrm{NS}$ \\
\hline
\end{tabular}

Abbreviations: NS, not significant; POST, posthydration; PRE, prehydration.

* Significant change in mortality, prehydration to posthydration. Paired $t$-test $(P \leq 0.05)$.

ture soil, insect mortality was $37 \%$ and $50 \%$ at $5 \mathrm{wk}$ in soils inoculated with $H$. bacteriophora (Tuscarora) and $H$. bacteriophora (Oswego), respectively but had declined to levels $\leq 8 \%$ by week 13 . Insect mortality in the S. glaseri-inoculated $9 \%$ soil began at $79 \%$ and gradually declined to $4 \%$ at week 74 . In the $12 \%$ soil, insect mortality was $68 \%-100 \%$ at week 5 for all three nematode isolates and declined to $11 \%-22 \%$ by week 74 . In the $15 \%$ soil, insect mortality in both $\mathrm{H}$. bacteriophora treatments was $100 \%$ at $5 \mathrm{wk}$ and decreased gradually over the $18 \mathrm{mo}$ of the experiment. The S. glaseri-inoculated soil at $15 \%$ moisture content induced only $77 \%$ insect mortality in the initial bioassay and declined more rapidly than other treatments.

Posthydration Insect Mortality. The results of bioassays in the rehydrated soil (i.e., posthydration) are paired with prehydration insect mortality levels and presented in Table 1. Significance is indicated when $P<0.05(\mathrm{df}=5)$. Insect mortality rebounded signif- icantly for both $H$. bacteriophora strains in the original $6 \%$ and $9 \%$ moisture soils throughout the 18 mo, with posthydration levels $83 \%-100 \%$. The effect was also evident in the H. bacteriophora (Oswego)-inoculated soil at $12 \%$ original moisture, with significant rebounds in insect mortality occurring in all but two bioassays (five and $61 \mathrm{wk}$ ). In the remaining three $H$. bacteriophora treatments $(H$. bacteriophora [Tuscarora] in $12 \%$ soil and both isolates in $15 \%$ soil), mortality was minimally affected by rehydration. Insect mortality in the check treatments was always $\leq 17 \%$, except at week 10 when all check mortality levels were increased to $20 \%-30 \%$. However, week 10 data were consistent with other bioassays and, therefore, were not removed from the analysis.

Soil Moisture. A slight decrease in soil moisture content over time had a significant effect but did not differ by nor interact with nematode treatment $(F=$ $100.87,78.83,48.47$, and 41.98 for $6 \%, 9 \%, 12 \%$, and $15 \%$ 


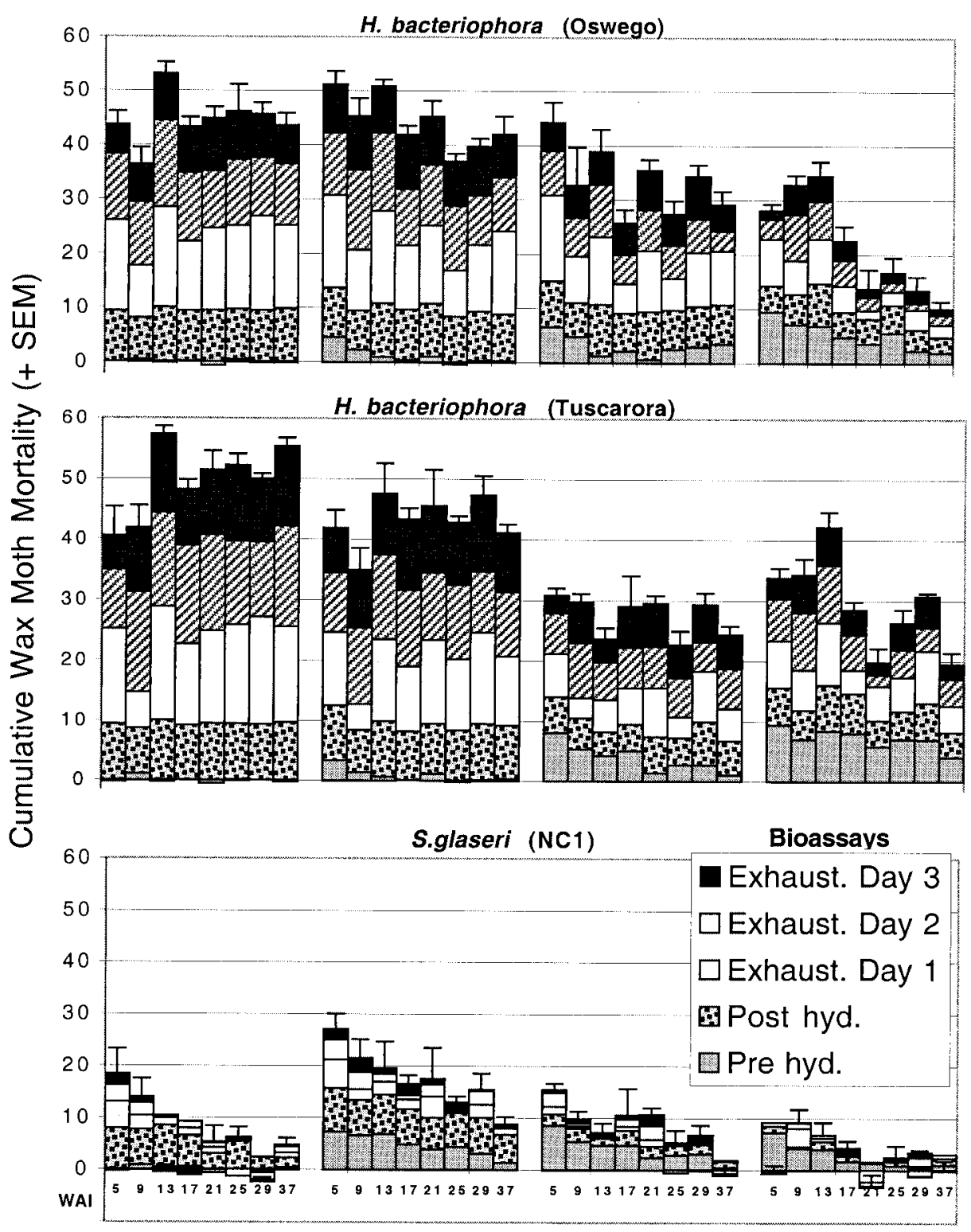

$6 \%$ Soil Moisture $\quad 9 \%$ Soil Moisture $12 \%$ Soil Moisture $15 \%$ Soil Moisture

Fig. 2. Cumulative insect mortality (CIM) in the long-term rehydration study, as a sum of mortality in the prehydration bioassay ( 10 possible), posthydration bioassay ( 10 possible), and three exhaustive bioassays ( 20 possible in each). Values were corrected by the control treatments (trt. total-control total). WAI $=\mathrm{Wk}$ after inoculation.

soil moisture, respectively; $\mathrm{df}=1,190 ; P=0.0001$ ). Overall mean soil moisture content was $5.44 \% \pm 0.37$ (6\% target), $8.46 \% \pm 0.43$ (9\% target), $11.38 \% \pm 0.49$ (12\% target), and $14.49 \% \pm 0.32$ (15\% target).

Exhaustive Bioassays and CIM. Insect mortality resulting from the exhaustive bioassays is shown as a component of the total CIM for each treatment (Fig. 2). The model for effects of nematode isolate, soil moisture, and time was complex, with all two and three-way interactions being significant. Therefore, each isolate was analyzed individually. For the S. glaseri treatments, soil moisture and time significantly affected CIM, but the factors did not interact (moisture effect $F=32.52 ; \mathrm{df}=3,160 ; P=0.0001$; time effect $F=10.70 ; P=0.0001 ; \mathrm{df}=7,160 ; P=0.0001 ;$ and interaction effect $F=0.86$; $\mathrm{df}=21,160$ ). CIM was significantly higher in the $9 \%$ soil moisture than all other moistures, which did not differ from each other. Within the S. glaseri treatments, CIM decreased significantly with time for all soil moistures. For the 
Table 2. Estimated model parameters, z statistics, and probabilities of obtaining by chance a larger absolute $\mathrm{z}$ from the logistic model of wax moth mortality data in the reactivation experiment

\begin{tabular}{lrrrr}
\hline \multicolumn{1}{c}{ Variable } & Coefficient & $\mathrm{SE}$ & $\mathrm{Z}$ & $P>|\mathrm{z}|$ \\
\hline $\begin{array}{l}\text { Nematode } \\
\quad \text { H. bacteriophora } \text { (Oswego) }\end{array}$ & -8.07 & 3.25 & -2.49 & 0.013 \\
$\begin{array}{l}\text { Nematode } \\
\quad \text { S. glaseri }\end{array}$ & 1.84 & 1.57 & 1.17 & 0.24 \\
$\begin{array}{l}\text { Soil moisture } \\
\text { Soil moisture } \times \text { H. bacteriophora }\end{array}$ & 1.11 & 0.13 & 8.56 & 0.00 \\
$\quad($ Oswego) & 0.92 & 0.36 & 2.56 & 0.01 \\
$\begin{array}{l}\text { Soil moisture } \times \text { S. glaseri } \\
\text { Constant }\end{array}$ & -0.44 & 0.16 & -2.75 & 0.06 \\
& -10.03 & 1.17 & -8.54 & 0.00
\end{tabular}

Oswego and Tuscarora strains of $H$. bacteriophora, CIM was generally highest in the $6 \%$ and $9 \%$ soil moistures. However, soil moisture significantly interacted with time, thereby necessitating individual comparisons at each bioassay time.

In the H. bacteriophora (Oswego) and H. bacteriophora (Tuscarora) treatments, high CIM levels in the low moisture soils compared with the high moisture soils resulted from higher mortality in the exhaustive bioassays (despite higher prehydration and posthydration bioassay mortality levels in the high moisture soils). In the $S$. glaseri treatments, insect mortality was highest in the $9 \%$ moisture soil for prehydration and posthydration bioassays, and for the exhaustive bioassays.

\section{Nematode Reactivation Study}

The reactivation study began in moderately low moisture soil (9\%), which was dried slowly over time until insect mortality was $\leq 7 \%$ in all treatments and not significantly different from the controls. This result occurred in the fifth bioassay (at $48 \mathrm{~d}$ ), when the soil moisture had dried to $5.2 \pm 0.05 \%$. At this point, nematodes were considered "inactive." Insect mortality in all control treatments in the post moistureadjustment bioassay was $\leq 10 \%$.

Estimated model parameters, z statistics, and probabilities of obtaining by chance a larger absolute $\mathrm{z}$ are shown in Table 2. Of most importance is that wax moth mortality increased with increasing soil moisture. However, this relationship was significantly different for each of the three nematode isolates (Fig. 3). Although the logistic model provided a reasonable description of the data, there was a significant lack of fit (chi-square with $24 \mathrm{df}=462.86, P<0.001$ ). Inspection of the data and predictions from the model show that in the lower part of the response curve, the model tended to over predict mortality, while in the upper part of the response curve, the model tended to underestimate mortality. In other words, the slope of the actual response was generally steeper than that for the estimated. Despite these shortcomings, the logistic model clearly portrays the pattern of the response and provides a concise comparison of the response among the three nematode strains. Insect mortality exceeded $20 \%$ in soil moistures $\geq 8 \%$ in the $H$. bacteriophora
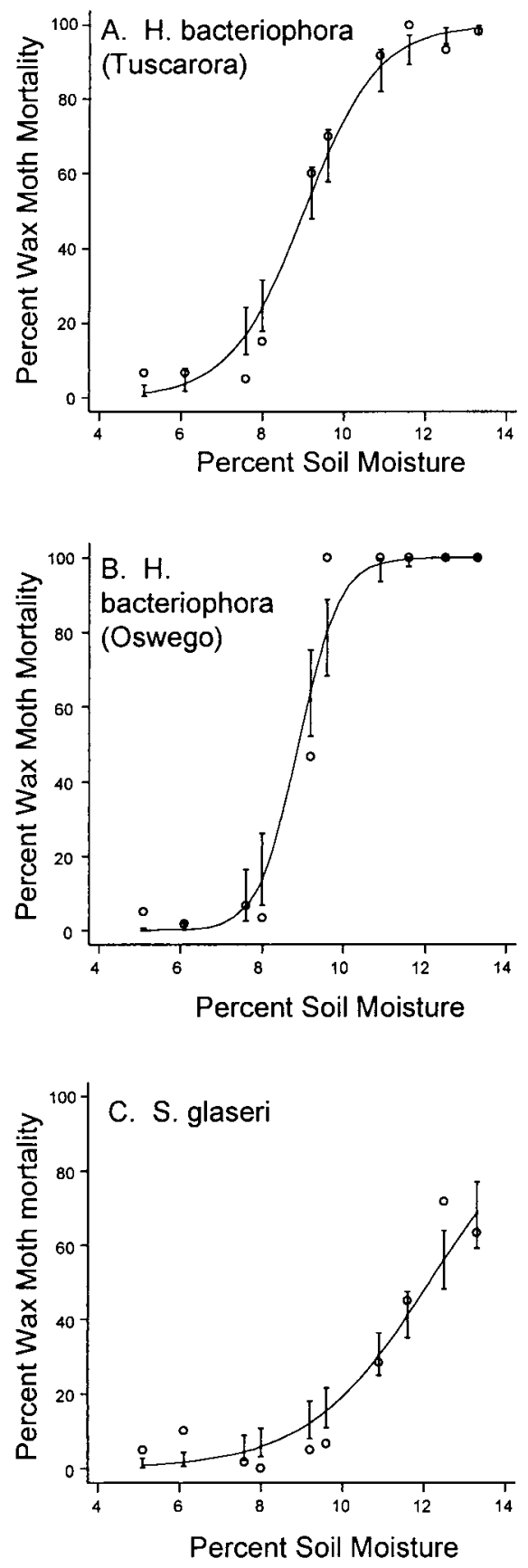

Fig. 3. Wax moth mortality in the nematode reactivation study, post moisture-adjustment. (A) H. bacteriophora (Tuscarora); (B) H. bacteriophora (Oswego); (C) S. glaseri (NC1). Open circles are data points. Bars illustrate $95 \%$ confidence intervals.

(Oswego and Tuscarora strains) and $\geq 10 \%$ in S. glaseri-inoculated soils. Overall, $H$. bacteriophora (Oswego) had the steepest slope and S. glaseri the shallowest. 


\section{Discussion}

In these studies, we monitored insect mortality but did not count nematodes in cadavers. Therefore, we were able to track a population's ability to infect and kill insects but not the survival or infectivity of individual nematodes. Our technique allowed us to run large-scale experiments, but did not track the fate of individual nematodes.

The prehydration bioassays in our first experiment simulated efficacy testing commonly done after field applications of nematodes. In this short-term indicator of nematode performance, both $\mathrm{H}$. bacteriophora isolates caused highest insect mortality in the highestmoisture soils. These results concur with current recommendations to apply nematodes to moist soils and irrigate after application. However, S. glaseri contradicted recommendations and performed best in relatively dry ( $9 \%$ moisture) soil during the short term.

By rehydrating the soils in this study, we simulated rainfall and irrigation events in the field, and tested how long nematodes could survive in a range of soil moistures and still be reactivated to infect insects. Both $H$. bacteriophora isolates showed an excellent long-term ability to survive in the low-moisture soils and be reactivated to cause high insect mortality throughout the 18 mo. Significant rebounds often occurred in the $12 \%$ moisture soil but never in the $15 \%$ moisture for both $H$. bacteriophora isolates. Higher prehydration insect mortality and lower posthydration mortality explain the lack of rebound. Follow-up with the exhaustive bioassays showed that these treatments had a minimal ability to cause further insect mortality. Infective nematodes may have been depleted from the system by several factors, such as infection of insects in earlier bioassays, weakness and death due to sustained activity in high-moisture soils, or succumbing to mortality factors favored by highmoisture soils.

S. glaseri response to soil moisture was markedly different from both $H$. bacteriophora isolates. At $9 \%$ soil moisture, $S$. glaseri performed better than it did at other soil moistures, both prehydration and posthydration, and had significant rebounds at most bioassay periods. The lower moisture preference of this nematode may make it better suited to cropping systems, where soil moisture is low to moderate, but not subject to extremely dry (below wilting point) moistures. However, our results show that S. glaseri was less able to tolerate extreme soil moisture conditions, both low and high, and the cumulative mortality induced by this nematode was much lower than both $H$. bacteriophora isolates. Improvements in efficacy and dehydrating ability will be necessary to make this nematode a viable pest management tool.

The long-term rebounding ability of $H$. bacteriophora nematodes has several practical implications. In turfgrass systems where soil moisture varies highly, nematodes may survive drought periods in an inactive state and become active again when conditions are more favorable. These conditions may exist in nonirrigated areas, especially with drought resistant peren- nial plants. It may also be possible to apply nematodes to low-moisture soil at a convenient time and later activate them with irrigation. Furthermore, examination of our cumulative mortality data revealed that $H$. bacteriophora nematodes applied to dry soils can cause higher insect mortality over a longer period of time than those applied to high-moisture soils.

Our reactivation study indicates that only moderate moisture levels are required to reactivate the nematode isolates tested. The threshold for activating nematodes inhabiting low-moisture soils was $\geq 8 \%$ soil moisture for H. bacteriophora (Oswego and Tuscarora strains), and $\geq 10 \%$ moisture for S. glaseri. In the sandy loam soil tested, these moistures correspond to -4 to -15 bars, levels at which plants can survive, but water is not readily available to them. Therefore, reactivation of inactive $H$. bacteriophora and S. glaseri nematodes in the field might be accomplished by the establishment of a new crop or irrigation of an existing dormant planting.

Our research also provides useful information for producers of entomopathogenic nematodes. Dehydration-induced quiescence has been used previously for commercial production and storage of nematodes in a variety of media (Grewal 1998). Therefore, differences in moisture response by various species and isolates are important in the formulation and storage of nematode products. Our work indicates specific levels of moisture required to activate nematodes in a soil environment. Desiccation and storage of nematodes in soil may be especially useful for cottage industries and farmers producing nematodes for local use in developing countries and other remote areas.

This work should be followed by more studies on environmental impacts on other species and isolates of entomopathogenic nematodes. Knowing more about tolerable soil moisture conditions for nematodes, growers and managers can better determine if nematode applications will be effective in specific field situations and can manage irrigation to stay within these limits. It may also be possible to take advantage of the survival ability of nematodes by applying nematodes early in the season and "activating" them with irrigation later in the season when an insect pest is present. Perennial plantings exposed to low-moisture conditions for long periods, such as residential turfgrass, could be an ideal system for exploring this concept.

\section{Acknowledgments}

We thank N. Consolie, W. Heusler, P. Robbins, and C. Reissig for laboratory assistance; N. Hummel and R. Schindelbeck for soil analyses; and F. Vermeylen and J. Nyrop for statistical consultation. This research was partially funded by the New York State Integrated Pest Management (IPM) program.

\section{References Cited}

Abbott, W. S. 1925. A method for computing the effectiveness of an insecticide. J. Econ. Entomol. 18: 265-267. 
Ames, L. 1990. The Role of Some Abiotic Factors in the Survival and Motility of Steinernema scapterisci. University of Florida, Gainesville, FL.

Boemare, N. E., A. Givaudan, M. Brehelin, and C. Laumond. 1997. Symbiosis and pathogenicity of nematode-bacterium complexes. Symbiosis 22: 21-45.

Curran, J. 1993. Post-application biology of entomopathogenic nematodes in soil, pp. 67-77. In R. Bedding, R. Akhurst, and H. Kaya (eds.), Nematodes and the Biological Control of Insect Pests. CSIRO, East Melbourne, Australia.

Fujiie, A., Y. Takata, M. Tachibana, and T. Yokoyama. 1996. Insecticidal activity of an entomopathogenic nematode, Steinernema Kushidai (Nematoda: Steinernematidae), against Anomala cuprea (Coleoptera: Scarabaeidae) larvae under different soil moisture conditions. Appl. Entomol. Zool. 31: 453-454.

Fujiie, A., and T. Yokoyama. 1998. Effects of ultraviolet light on the entomopathogenic nematode, Steinernema Kush$i d a i$ and its symbiotic bacterium, Xenorhabdus japonicus. Appl. Entomol. Zool. 33: 263-269.

Gaugler, R., A. Bednarek, and J. F. Campbell. 1992. Ultraviolet inactivation of heterorhabditid and steinernematid nematodes. J. Invertebr. Pathol. 59: 155-160.

Gaugler, R., E. Lewis, and R. J. Stuart. 1997. Ecology in the service of biological control: The case of entomopathogenic nematodes. Oecologia (Berl.). 109: 483-489.

Georgis, R., and S. A. Manweiler. 1994. Entomopathogenic nematodes: A developing biological control technology. Agric. Zool. Rev. 6: 63-94.

Grant, J. A., and M. G. Villani. 2003. Soil moisture effects on entomopathogenic nematodes. Environ. Entomol. 32: 80 87.

Grewal, P. S. 1998. Formulations of entomopathogenic nematodes for storage and application. Japanese J. Nematol. 28: $68-74$.

Griffin, C. T. 1993. Temperature responses of entomopathogenic nematodes: Implications for the success of biological control programmes, pp. 115-126. In R. Bedding, R. Akhurst, and H. Kaya (eds.), Nematodes and the Biological Control of Insect Pests. CSIRO, East Melbourne, Australia.

Hillel, D. 1998. Environmental Soil Physics. Academic, San Diego, CA.

Kaya, H. K., and R. Gaugler. 1993. Entomopathogenic Nematodes. Annu. Rev. Entomol. 38: 181-206.

Kaya, H. K. and S. P. Stock. 1997. Techniques in insect nematology, pp. 281-324. In L. A. Lacey (ed.), Manual of Techniques in Insect Pathology. Academic Limited, San Diego, CA.
Klein, M. G. 1990. Efficacy against soil-inhabiting insect pests, pp. 195-214. In R. Gaugler and H. Kaya (eds.), Entomopathogenic Nematodes in Biological Control CRC, Boca Raton, FL.

Koppenhöfer, A. M., H. K. Kaya, and S. P. Taormino. 1995. Infectivity of entomopathogenic nematodes (Rhabditida: Steinernematidae) at different soil depths and moistures. J. Invertebr. Pathol. 65: 193-199.

Kung, S. P., R. Gaugler, and H. K. Kaya. 1991. Effects of soil temperature moisture and relative humidity on entomopathogenic nematode persistence. J. Invertebr. Pathol. 57: 242-249.

Portillo-Aguilar, C., M. G. Villani, M. J. Tauber, C. A. Tauber, and J. P. Nyrop. 1999. Entomopathogenic nematode (Rhabditida: Heterorhabditidae and Steinernematidae) response to soil texture and bulk density. Environ. Entomol. 28: 1021-1035.

SAS Institute 1996. SAS/STAT Software computer program, version 6.12 ed. SAS Institute, Cary, NC.

Simoes, N., and J. S. Rosa. 1996. Pathogenicity and host specificity of entomopathogenic nematodes. Biocontrol Sci Tech 6: 403-411.

Simons, W. R., and G. O. Poinar. 1973. The ability of Neoaplectana carpocapsae (Steinernematidae: Nematodea) to survive extended periods of desiccation. J. Invertebr. Pathol. 22: 228-230.

Smith, K. 1999. Factors affecting efficacy, pp. 37-46. In S Polavarapu (ed.), Optimal Use of Insecticidal Nematodes in Pest Management. Rutgers University, New Brunswick, NJ.

Smits, P. H. 1996. Post-application persistence of entomopathogenic nematodes. Biocontrol Sci. Tech 6: 379387.

StataCorp. 2001. Stata Statistical Software, release 7.0. College Station, TX

White, G. F. 1927. A method for obtaining infective nematode larvae from cultures. Science 66: 302-303.

Womersley, C. Z. 1990. Dehydration survival and anhydrobiotic potential, pp. 117-137. In R. Gaugler and H. Kaya (eds. ), Entomopathogenic Nematodes in Biological Control. CRC, Boca Raton, FL.

Womersley, C. Z., D. A. Wharton, and L. M. Higa. 1998 Survival biology, pp. 271-302. In R. N. Perry and D. J. Wright (eds.), The Physiology and Biochemistry of FreeLiving and Plant-Parasitic Nematodes. CABI Publishing, Wallingford, United Kingdom.

Received for publication 2 October 2002; accepted 14 May 2003 